KAWISTARA

VOLUME $3 \quad$ No. 3, 22 Desember 2013

Halaman 227-334

\title{
AKSIOLOGI TARI BEDHAYA KRATON YOGYAKARTA
}

\author{
Sunaryadi \\ Fakultas Seni Pertunjukan \\ Institut Seni Indonesia - Yogyakarta \\ Email: kabanram@yahoo.com
}

\begin{abstract}
Bedhaya at Palace dance was originally a sacred dance that is laden with symbols of life because it's not just a dance movement, but an action that is displayed and that becomes the life reference. Bedhaya is presented as a mirror of Javanese culture axiological which includes ethical and aesthetic values. It is a reflection of manunggaling kawula-Gusti in terms of its ethical dimension and it has the aesthetic values of the motion, fashion, and makeup. Bedhaya dance philosophy is summaried in the doctrine of ngelmu sangkan paran covering three things: the first it's related to the human consciousness that comes from God (urip iki saka sapa); the second, it is irelated to the duties and obligations of human beings in the world (urip iki arep apa); and the third, it is related to man's return to his Lord (urip iki pungkasane piye). Therefore, in the moral ethics context, Javanese life purpose is how to be a good man to reach the manunggaling kawula with Gusti as it is believed that goodness and beauty (mind) are the manifestation of the Essence of the Most Holy. The journey of human life portrayed in lampah bedhaya of majeng beksa, beksa to mundur beksa is a role model to determine the choice between good and bad .
\end{abstract}

Keywords: Axiology, Bedhaya, Ethical, and Aesthetic.

\section{ABSTRAK}

Tari bedhaya di Kraton Yogyakarta pada awalnya merupakan tarian sakral yang sarat dengan simbol kehidupan karena tarian itu bukan sekedar gerakan, tetapi merupakan aksi yang ditampilkan dan menjadi acuan hidup. Bedhaya hadir sebagai cermin dari budaya masyarakat Jawa yang secara aksiologis memuat nilai etis dan estetis. Ia merupakan refleksi dari ajaran manunggaling kawula-Gusti ditinjau dari dimensi etisnya dan mengemban nilai-nilai estetis dilihat dari gerak, tata busana, dan tata riasnya. Filosofi tari bedhaya terangkum dalam ajaran ngelmu sangkan paran yang meliputi tiga hal, yaitu pertama berkenaan dengan kesadaran bahwa manusia berasal dari Tuhan (urip iki saka sapa); kedua, berkaitan dengan tugas dan kewajiban manusia di dunia (urip iki arep apa); dan ketiga, berhubungan dengan kepulangan manusia kembali kepada Tuhannya (urip iki pungkasane piye). Oleh karena itu, dalam konteks etika moral, tujuan hidup manusia Jawa adalah bagaimana menjadi manusia yang baik untuk mencapai manunggaling kawula dengan Gusti tersebut karena diyakini bahwa kebaikan dan keindahan (budi) merupakan perwujudan dari Dzat Yang Maha Suci. Perjalanan hidup manusia yang tergambarkan dalam lampah bedhaya dari majeng beksa, beksa hingga mundur beksa, menjadi panutan untuk menentukan pilihan antara baik dan buruk.

Kata Kunci: Aksiologi, Bedhaya, Etis, dan Estetis 


\section{PENGANTAR}

Tari bedhaya di Surakarta dan Yogyakarta merupakan sebuah bentuk tarian klasik yang dianggap mempunyai kekuatan religiusmagis sekaligus juga diyakini sebagai salah satu bentuk pusaka kraton (Maharsiwara, 2007: 95). Pada awal keberadaannya tarian ini digunakan sebagai tari peresembahan pada upacara-upacara di kraton, yaitu persembahan kepada Sang Pencipta (penguasa jagad raya). Oleh karena itu, tari bedhaya hanya boleh dipentaskan di tempat terbatas dan disaat tertentu, seperti pada ulang tahun raja, memperingati berdirinya kraton, atau untuk memperingati hari penobatan raja, walaupun dalam proses berikutnya tari bedhaya akhirnya berubah dari fungsi ritual ke fungsi hiburan. Akhir-akhir ini terlihat ada upaya untuk menempatkan kembali fungsi tari bedhaya dalam bingkai ritual, yaitu dengan digalinya kembali tari Bedhaya Semang karya Sultan Hamengkubuwana I (Maharsiwara, 2007: 95).

Sesunggguhnya tari kraton tidak terkecuali bedhaya, mengandung beragam nilai seperti filsafat hidup dan sistem pengetahuan yang mencerminkan pola masyarakatnya. Artinya, keberadaan tari itu selalu terkait dengan sistem simbol dan sistem nilai masyarakat tertentu (Soedarso, 1980: 24). Secara aksiologis memuat nilai etis sebagai tuntunan hidup terkait dengan masalah-masalah moral serta nilai estetis yang menghadirkan keindahan gerak, bentuk dan lain sebagainya. Bertolak dari keunikan itu, tulisan ini ingin mengupas tari bedhaya dari sisi aksiologinya, yaitu muatan nilai etis dan estetis yang diembannya.

Metode penelitian yang dipakai untuk mengungkap tari kraton adalah metode penelitian deskriptif-kualitatif karena penelitian ini menyangkut pengertian tentang konsep, nilai, ciri-ciri, serta hubungan antarunsur-unsur yang ada di dalam sebuah karya tari, bagaimana nilai-nilai itu berpengaruh pada filsafatnya (Joged Mataram) sebagai dasar pembentuk karakter dalam kehidupan kraton, dan relevansinya dengan kehidupan masyarakat saat ini. Objek material dalam penelitian berkaitan dengan nilai-nilai dan pandangan hidup karena pada penelitian ini diperlukan pula metode kualitatif naturalistik termasuk metode grounded recearch. Para ahli menyebut metode penelitian ini dengan beragam nama antara lain etnography atau metode kualitatif. Studi semacam itu dikenal pula dengan istilah pendekatan multidisipliner yang banyak digunakan di berbagai disiplin ilmu, antara lain di bidang ilmu filsafat dan ilmu humaniora.

Ciri penelitian kualitatif memerlukan sasaran penelitian seperti adanya subyek penelitian, proses sosial yang menjadi titik perhatian, analisis data yang bersifat deskriptif dan induktif, serta keberadaan 'makna' yang menjadi esensi penelitian. Dalam hal ini buku tulisan Kaelan berjudul Metode Penelitian Kualitatifbidang Filsafat (2005) digunakan untuk mendiskripsikan tari kraton secara utuh (deskriptif-kualitatif), sehingga nampak fakta-fakta filosofisnya. Metode ini banyak digunakan untuk penelitian yang menyangkut tentang manusia dengan segala hasil budayanya, sehingga diharapkan memperoleh gambaran yang komprehensif terhadap masalah yang diteliti.

\section{PEMBAHASAN}

Ditinjau dari sisi kebahasaan, aksiologi berasal dari dua kata axios istilah Yunani yang berarti layak atau pantas dan logos yang berarti ilmu atau studi mengenai suatu hal (Bagus, 2002: 33). Secara terminologis aksiologi merupakan ilmu yang meneliti tentang nilai-nilai (Blackburn, 1994: 32). Sesungguhnya 'nilai' tidak dapat dilepaskan dari syarat dan kondisi yang melingkupinya, yaitu (a) suatu subjek yang memberi nilai; (b) suatu objek yang diberi nilai; (c) suatu perbuatan penilaian; (d) suatu nilai ditambah dengan penilaian (Kattsoff, 2004: 321). Umumnya, filsuf dan pemikir memahami nilai dalam beberapa konteks sebagai berikut: (a) nilai merupakan kualitas empiris yang tidak dapat didefinisikan; (b) nilai sebagai obyek dari kepentingan; (c) nilai sebagai hasil pemberian nilai; dan (d) nilai sebagai esensi.

Ditinjau dari karakteristiknya, sebuah nilai dipastikan mempunyai ciri khas 
mendasar, yaitu parasitis, polaritas, dan hierakis (Frondizi, 1963: 5-10). Pertama, nilai dianggap sebagai suatu yang bersifat parsitis karena nilai merupakan kualitas tidak dapat hidup tanpa didukung oleh objek lain yang menjadi dasarnya. Kedua, nilai selalu dipandang dalam konteks polaritas, yaitu nilai menampakkan dirinya dalam situasi yang berlawanan dan bersebrangan, misalnya "baik" dan "buruk". Ketiga, nilai juga hadir dalam kehidupan manusia dalam wujudnya yang berjenjang atau hierarkis.

Persoalan yang cukup krusial dalam wacana nilai terletak pada perdebatan hakikat nilai itu sendiri, apakah nilai itu subjektif atau nilai merupakan suatu wujud yang objektif. Para subjektivis nilai beranggapan bahwa nilai itu bersifat subjektif. Mereka berpandangan bahwa istilah nilai menunjukkan perasaan, emosi, atau mental dalam bentuk suka atau tidak suka. Nilai itu ada di alam akal budi. Kepuasan keinginan merupakan nilai yang sesungguhnya, sedangkan benda yang mengantarkan kepada kepuasan itu hanya alat. Nilai merupakan refleksi pengalaman, bukannya benda atau obyek tertentu. Sebuah benda boleh jadi mungkin berharga, tetapi bukan nilai. Faktanya, seseorang memproyeksikan nilai itu ke dunia luar dan mengiranya sebagai benda yang memuaskan keinginannya (Titus, 1984: 123 - 124). Salah satu filsuf yang berpandangan bahwa nilai itu subjetif adalah Ralp Barton Perry (1954: 3). Perry memandang bahwa nilai itu merupakan kepentingan subjek atas objek. Artinya, sebuah objek tertentu bernilai apabila ia diperhatikan oleh subjek. Jadi perhatian subjek atas objek melahirkan apa yang disebut nilai.

Lawan dari subjektivisme nilai adalah paham objektivisme nilai. Para penganut objektivis nilai beranggapan bahwa nilai merupakan sesuatu yang terpisah dari pengamatnya, nilai itu terletak di dalam benda sebagai objek pengamatan. Nilai itu mengada sebagai kualitas yang melekat pada benda, bukan karena penilaian atau persepsi pengamatnya (Titus, 1984: 124).

Salah satu pendukung objektivisme nilai adalah Max Scheler. Scheler berpandangan bahwa nilai merupakan kualitas yang tidak tergantung pada pembawanya, nilai merupakan kualitas a priori yang dirasakan seeorang tanpa melalui pengalaman indrawi terlebih dahulu. Nilai bersifat absolut tidak dipengaruhi oleh sesuatu di luar dirinya, baik secara kesejarahan, sosial, biologis, dan seterusnya. Nilai merupakan objek yang bersifat ideal, bersifat tetap tidak terpengaruh oleh apapun. Nilai objektif itu secara hierarkis saling terhubung satu sama lain yang meliputi nilai kesenangan, nilai vitalitas, nilai spiritual, dan nilai kesucian (Scheler, 1973: 104 - 110).

Perdebatan subjektivisme dan objektivisme nilai di atas telah dicoba untuk dijembatani oleh para pemikir misalnya Resieri Frondizi. Menurut Frondizi, sebuah nilai itu sangat terkait dengan situasi dan kondisi yang dibentuk oleh anasir kompleks dan rumit dari suasana individual, sosial, budaya, dan sejarah. Nilai itu hadir dan menemukan wujudnya hanya di dalam situasi yang nyata dan tertentu seperti yang dikatakan oleh Frondizi (1963: 140) sebagai berikut:

"If the name "situation" is applied to the complex of individual, social, cultural, and historical elements and circumtances, then we maintain that value have axistence and meaning only within a concrete and definite situation."

Itulah uraian mengenai pengertian aksiologi, hak ikat nilai, dan paham-paham sekitar nilai.

\section{Nilai dalam Budaya Jawa}

Istilah "jawa" secara kebahasaan diartikan tahu adat, tahu aturan, tahu siapa dirinya. Pengertian itu berarti juga ketundukan pada hukum-hukum yang telah ditentukan oleh Tuhan. Biasanya kata Jawa menunjuk pada suatu komunitas, suku, atau pulau tertentu di Nusantara ini. Secara Antropologi Budaya yang disebut orang Jawa adalah mereka yang berdomisili di tanah Jawa dan mempergunakan bahasa pengantar Bahasa Jawa dalam kehidupan sehari-hari (Koentjaraningrat, 1976: 322). Masyarakat Jawa sebagai sebuah komunitas mempunyai sistem nilainya sendiri. Perbincangan mengenai nilai, sebagaimana telah digambarkan terdahulu merupakan persoalan 
aksiologi. Umumnya, aksiologi menelaah dua tema besar, yaitu etika (kesusilaan) dan estetika (keindahan). Etika (ethics) secara etimologis merupakan kata turunan dari "ethos" dalam bahasa Yunani yang berarti "karakter", kebiasaan, adat, atau praktik. Ditinjau dari aspek terminologisnya, aksiologi dipahami sebagai cabang filsafat yang menelaah konsepkonsep yang berkaitan dengan pemikiran praksis tentang kebaikan, hak, kewajiban, kebebasan, rasionalitas, dan pilihan. Aksiologi juga merupakan studi tentang teori-teori objektivitas, subyekivitas, relativisme, atau skeptisisme yang hadir dalam menyingkapi persoalan-persoalan etik (Blackburn, 1994: 126, Bagus, 1996: 217). Istilah etika pertama kali diperkenalkan oleh Aristoteles. Lebih lanjut Cicero memperkenalkan istilah moralis. Baginya kata tersebut ekuivalen dengan kata ethikos, keduanya menunjuk pada kegiatan praksis.

Etika dalam alam pikiran Jawa dikaitkan erat dengan baik-buruk. Baik-buruk dalam etika Jawa merupakan problem yang inheren dari eksistensi manusia yang terejawantah dalam beragam keinginan yang berkorelasi dengan empat nafsu (baca: mutmainah, amarah, lawwamah, dan supiah). Ada pola hubungan kontradiktif yang tidak tidak dapat dinafikan antara keinginan baik (mutmainnah) yang selalu bersebrangan dengan keinginan buruk (amarah, lawwamah, dan supiah). Demi kesempurnaan sebagai tujuan hidup manusia dalam bentuk terwujudnya sifat ilahi yang disebut dengan manunggaling kawulo-Gusti, alam pikiran Jawa berasumsi bahwa hubungan antara baikburuk bisa dilampaui dengan cara peningkatan kesadaran. Dalam terminologi Jawa kesadaran itu dikenal juga dengan kadewasaning jiwa atau kematangan jiwa manusia. Jadi, kesusilaan atau moralitas bagi alam pikiran Jawa berada dalam kerangka cipta-rasa-karsa manusia menuju kesempurnaan. Tingkat kematangan jiwanya akan menentukan moralitas manusia tersebut. Lebih jauh, etika Jawa didasarkan nilai-nilai yang khas, yakni kerukunan, prisnip hormat, dan keselarasan sosial (Suseno, 2001: 38-81).

Estetika secara harfiah berasal dari bahasa Yunani "Aisthetika" yang berarti halhal yang dapat diserap oleh pancaindera. Oleh sebab itu, estetika saat ini sering didefinisikan sebagai persepsi indera (sense of perception). Orang yang pertama kali memperkenalkan kata "aisthetika" adalah Alexander Baumgarten (1714-1762). Ia merupakan filsuf kelahiran Jerman yang meneruskan gagasan-gagasan Cottfried Leibniz (1646-1716). Kata "aisthetika" ia pergunakan demi memberi tekanan pada pengalaman seni sebagai suatu sarana untuk mengetahui (the perfection of sentient knowledge), meskipun demikian umumnya estetika diartikan sebagai salah satu cabang filsafat yang mengkaji gejala yang indah pada alam dan karya seni (Dharsono, 2004: 5). Misalnya The Oxford Dictionary of Philosophy memberikan defenisi sebagai berikut:

\begin{abstract}
"the study of the feelings, concepts, and judgments arising from our appreciation of the arts or of the wider class of objects considered moving, or beautiful, or sublime. Aesthetics theory concerns itself with questions such us..." (Blackburn, 1994: 8).
\end{abstract}

Singkatnya, estetika dalam arti yang paling sempit adalah kajian tentang keindahan. Nyatanya, dalam sejarah filsafat tercatat bahwa semenjak zaman Yunani Kuno sampai abad ke-18, ide pokok dari estetika adalah masalah yang berkaitan dengan keindahan (beauty) (Dharsono, 2004: 2), meskipun mulai abad ke18 pengertian estetika tidak hanya dipahami sebagai problem keindahan saja. Dalam hal ini estetika Jawa sangat dipengaruhi oleh dua arus besar religi dan budaya yaitu Hindu dan Islam. Keindahan bagi Jawa-Hindu selalu dianggap sebagai pengejawantahan yang mutlak karena bagi penganutnya keindahan adalah satu (monistik), sedangkan Jawa-Islam merupakan analog dari 20 sifat dan 99 nama Allah yang indah (al-Asma' al-Husna) yang direduksi menjadi 4 sifat yaitu Agung (Jalal), Elok (Jamal), Wisesa (Kahar atau Kuasa), dan sempurna (kamal).

\section{Dimensi Nilai Tari Bedhaya Nilai Etis}

Tari bedhaya merupakan salah satu tarian ritual yang penuh dengan nilai dan pesan moral, sehingga wajar apabila sampai 
dekade pertengahan akhir tahun 2000, tetap dipertahankan keberadaannya terutama bagi lingkungan istana baik di Surakarta maupun Yogyakarta. Tarian ini di Kraton Surakarta tetap dilestarikan hingga sekarang dalam bentuk tari Bedhaya Ketawang. Di Yogyakarta taribedhayaitu seolah mendapat tempat ke dua sesudah wayang wong, tetapi pentas bedhaya tetap diagungkan dan disakralkan, terbukti para sultan tetap berupaya menciptakan satu bentuk bedhaya tersendiri, yang dapat menjadi ciri khas masa pemerintahannya.

Pentas tari bedhaya di Kraton Yogyakarta semula diadakan di Bangsal Kencana dekat dengan tempat duduk Sultan. Itu menunjukkan bahwa sesungguhnya tari bedhaya adalah sebuah tarian sakral yang sangat tinggi kedudukannya. Oleh karenaitu, pada masa lalu raja dianggap sebagai wakil Tuhan di dunia, maka bedhaya juga menjadi simbol hubungan antara manusia dengan Tuhannya, sebagaimana tujuan hidup manusia Jawa dalam mewujudkan cita-cita manunggaling kawula-Gusti (Soedarsono,1997: 143-149). Cita-cita mengenai kesatuan antara ke-aku-an (manusia) dengan Yang Ilahi, di mana "aku" (batin) telah berhasil melepas belenggu lahir yang berupa nafsu-nafsu hingga yang tinggal hanya sifat-sifat Ilahi.

Melalui kesatuan itu, maka manusia (Jawa) dapat mencapai kawruh "sangkan paraning dumadi" yaitu kawruh (pengetahuan) tentang asal (sangkan) dan tujuan (paran) dari segala yang diciptakan (dumadi) (Suseno, 2001:117-120). Cita-cita tersebut bisa dicapai dengan membangun "keselarasan" hidup, keselarasan antara perkataan, pendengaran, penglihatan, dengan pikiran dan perasaan untuk menuju kebahagiaan dunia dan akherat. Butir-butir faham Jawa ini sebenarnya masih relevan sebagai pedoman hidup bermasyarakat dalam membangun ketentraman bersama.

Dalam kaitannya dengan konsep dunia akhirat dan sangkan paraning dumadi itu, maka dapat ditelusuri melalui lewat filosofi tari bedhaya. Menurut K.P.H. Brongtodiningrat seorang Empu Tari Kraton Yogyakarta sejak masa pemerintahan Sultan Hamengku
Buwana VII (tahun 1877 - 1921), Hamengku Buwana VIII (tahun 1921 - 1939) sampai pertengahan pemerintahan Sultan Hamengku Buwana IX (tahun 1939 - 1988), menafsirkan bahwa formasi bedhaya menggambarkan proses perjalanan spiritual anak manusia dari purwa (awal), madya (yang dijalani di dunia nyata), wasana (sebagai insan kamil atau manusia sempurna), yang kadang harus dihadapkan pada dilema antara menuruti keinginan logika atau kebutuhan batin.

Bedhaya yang ditarikan oleh sembilan penari putri itu menjadi simbol sembilan lubang yang terdapat pada badan wadhag (jasmani) manusia, sebagai simbol mikrokosmos dari jagading manungsa yang terdiri dari dua mata, dua lubang hidung, dua lubang telinga, mulut, thubur (anus), dan alat kelamin. Di dunia pedalangan organ tubuh manusia itu sering disebut dengan babahan hawa sanga. Ketika seseorang berkeinginan meraih sesuatu dengan cara bersemedi, bermeditasi, mesubudi mendekatkan diri kepada Tuhan, maka dia harus mampu pati rasa (memusatkan pikiran kepada Yang Tunggal), dan pati raga menutup sembilan lubang yang menjadi sumber segala nafsu (amarah, lauamah, dan supiah). Artinya dia harus dapat mengatasi godaan yang berasal dari penglihatan, pendengaran, penciuman, mulut/ perasa, serta nafsu seks.

Tari bedhaya gaya Yogyakarta pada intinya terdiri dari lima (5) pola pokok (Sunaryadi. 2012.: 339-342) sedangkan polapola yang lainnya kebanyakan berupa pengulangan gerak, komposisi, atau merupakan suatu proses pergantian dari komposisi satu ke komposisi yang lain. Adapun pola pokok itu terdiri dari: rakit lajur, reakit ajeng-ajengan, rakit iring-iringan, rakit tiga-tiga, dan rakit gelar.

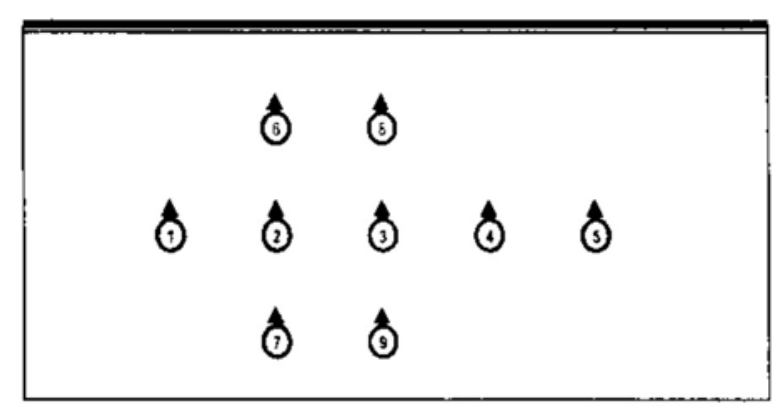

Gambar 1. Komposisi Rakit Lajur 
Komposisi 'rakit lajur' digunakan dalam formasi tari bedhaya pada saat memasuki arena pentas dan saat keluar arena, yang menggambarkan jasmani manusia dari kepala hingga kaki, dengan lima penari di tengah (endhel pajeg, batak, jangga, dhadha, bunthil), dan empat penari di kiri-kanan (apit ngajeng, apit wingking, endhel wedalan ngajeng, dan endhel wedalan wingking). Dengan demikian komposisi lajur ini terdiri dari bilangan empat dan lima. Menurut kosmologi Jawa angka empat mewakili pengertian tentang keblat papat atau empat arah mata angin yang membatasi alam semesta, yaitu arah timur, selatan, barat, dan utara. Keblat papat dalam pengertian budaya Jawa mencakup satu bilangan yang ada di tengah sebagai pokok atau pancer (keblat papat lima pancer). Posisi manusia yang berada di tengah sebagai pancer menyebabkan manusia memiliki peran penting dalam memelihara harmoni kosmos, atau sebaliknya justru akan mengakibatkan chaos (kekacauan). Terwujudnya harmoni atau keteraturan sangat ditentukan oleh moralitas manusianya. Semesta akan tenteram, damai karena peran dan tindakan manusia sebagai "pusat", sebaliknya bencana dan kesengsaraan juga merupakan akibat dari olah manusia.

Bilangan empat selain mewakili pengertian keblat papat, juga mencakup pengertian tentang keberadaan sedulur papat atau kadang papat (empat saudara yang lahir bersamaan dengan manusia, berupa ketuban, darah, plasenta, dan tali pusar). Sedulur papat diyakini akan mempengaruhi ekstensi identitas individualitas masingmasing orang. Dalam kaitannya dengan falsafah bilangan lima dan empat pada tari bedhaya, Brongtodiningrat lebih condong kepada pengertian tentang adanya lima mudah, dengan empat anasir yang merupakan gambaran mengenai asaling manungsa (asal manusia) atau asaling dumadi. Asaling manungsa dimulai dari keberadaan alam semesta yang bermula dari dzat, kemudian lahirlah sifat, keduanya saling mempengaruhi sehingga menimbulkan hidup. Hidup baru sempurna setelah dilengkapi dengan lima unsur kehidupan atau lima mudah, yang terdiri dari roh (jiwa), nur (cahaya), rahsa (rasa), budi (kepribadian), dan napsu, yang berasal dari empat anasir atau empat kekuatan yaitu air, api, angin, dan bumi atau tanah.



Gambar 2. Komposisi Rakit Ajeng-ajengan

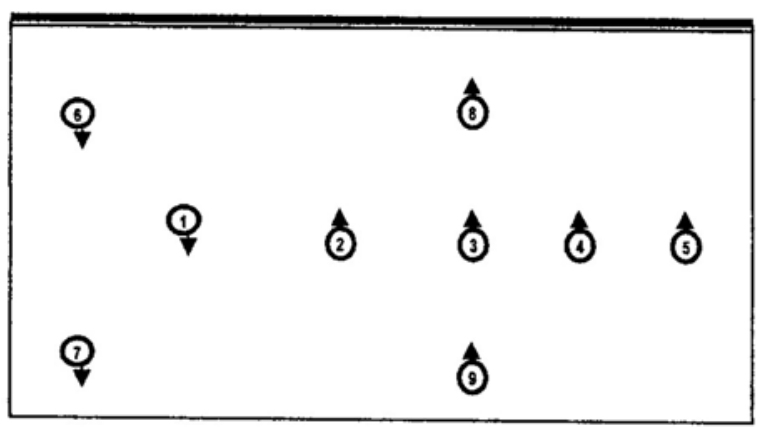

Gambar 3. Komposisi Rakit Iring-iringan

Perjalanan hidup yang harus dilalui manusia untuk kembali bersatu denganNya tentu tidak mulus, tetapi penuh dengan rintangan atau intrik tertentu. Berbagai rintangan hidup itu digambarkan dengan peperangan antara penari batak dan endhel yang kadang keluar dari formasi, sebagai simbol ketidak sesuaian antara kehendak (rasa/ rohani) dengan logika (pikiran/ duniawi) yang sering terjadi dalam kehidupan manusia. Demikian pula dengan keluar masuknya 'apit' ke dalam formasi 'lajur' menjadi simbol ketidakstabilan suasana hati manusia.

Gambaran keragu-raguan batin manusia dalam mengambil keputusan antara memilih yang baik, kurang baik, atau bahkan tidak baik itu, divisualisasikan ke dalam formasi 'rakit ajeng-ajengan' (batak dan endhel saling berhadapan). Apabila yang baik yang diambil, maka dunia akan tenteram damai dan tercapai cita-cita jumbuhing kawula lan Gusti. Apabila 
yang buruk diambil, maka dunia akan rusak. Pilihan itu merupakan resiko yang harus dipertanggungjawabkan secara moral.

Formasi dari 'rakit ajeng-ajengan' (tiga penari di sebelah kiri, enam penari di kanan dengan posisi dua penari utama: endhel pajeg sebagai refleksi hati/batin dan batak yang mewakili gambaran kepala/pikiran itu dalam posisi saling berhadapan), hingga formasi 'rakit iring-iringan' merupakan gambaran pertentangan antara rasa dengan logika yang diaplikasikan secara halus, lembut, sesuai dengan etika keutamaan Jawa. Dalam tulisannya, Retno Pujiastuti mengatakan bahwa pertentangan antara batak dan endhel itu tidak diungkapkan dengan posisi bersitegang, sebaliknya mereka mengkomunikasikan perbedaan peran dan karakter itu, ke dalam suatu dialog gerak yang dinamis, selaras, dan harmonis. Oleh karena itu, seluruh gerak tari, ritme, dan irama gendhing harus dilakukan dengan serba teratur terkendali (mbanyumili) dalam tempo yang konstan (ajeg) (Maharsiwara, 2007: 102).

Akhir peperangan menunjukkan bahwa pergolakan antara emosi dengan rasa itu harus diakhiri dengan persatuan kembali sebagai loro-loroning a tunggal. Artinya bahwa kedua sifat yang bertentangan itu, harus diupayakan selalu dalam taraf keseimbangan. Nilai etis yang terkandung dalam formasi rakit ajeng-ajengan dan iring-iringan adalah unsur 'mawas diri' (mau mengakui kekurangan diri sendiri), serta mampu mengendalikan diri, karena kebahagiaan sejati baru didapat apabila antara perintah otak dan perintah batin terjalin satu kesatuan.

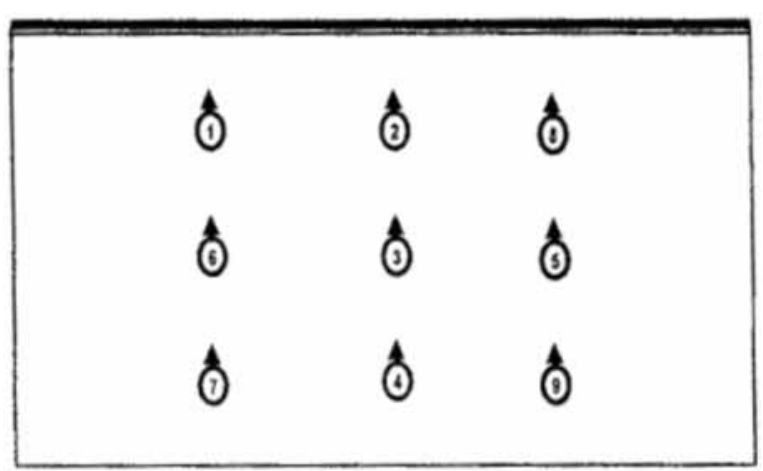

Gambar 4. Posisi Pola Rakit Tiga-tiga
Proses kehidupannya, manusia harus melewati tiga tingkatan baitul makmur, baitul mukharam, dan baitul muqadas, yang dalam bahasa pewayangan disebut dengan 'triloka' (menurut faham Hindu). Di dalam tari bedhaya hal itu dijabarkan dalam bentuk formasi rakit tiga-tiga. Formasi ini merupakan manifestasi batin yang di dalamnya memiliki tiga kekuatan atau 'tripusara' berasal dari otak, hati, dan rongga perut. Tiga-tiganya harus nyawiji, bersatu menjadi simbol telu-teluning atunggal atau Trimurti (air, api, dan angin) yang akan menghasilkan pramana (kekuatan). Air (sarining toya) menghasilkan roh jasmani, nurani, roh kabati, dan roh hewani. Udara (swasana) atau angin, menghasilkan napas (nafas), ampas (nafas atau udara atau angin yang kurang baik), tanapas (nafas yang tidak teratur), dan nupus (tanpa nafas). Api (bagaskara atau matahari) menghasilkan napsu patang perkara (empat nafsu) yaitu nafsu amarah (kemarahan), lauwamah (nafsu makan), supiah (belum dapat mengendalikan diri), dan mutmainah (kebaikan).

Tiga kekuatan yang dihasilkan itu, berasal dari tiga dunia atau triloka yaitu Pertama, alam janaloka atau alam wadhag (alam fana) berupa tubuh, tempat segala godaan, dan keinginan. Kedua, alam guruloka (alam perasaan) sumber rasa sejati yang membawa rasa senang, puas, setia, dan sebagainya. Ketiga, alam indraloka (alam pikiran) tempat bersemayamnya daya cipta, karsa, dan angan-angan. Itulah penjabaran dari 'rakit tiga-tiga' bahwa manusia di dalam hidupnya harus mampu melalui tiga tingkatan, tiga dunia, atau tiga alam yang berhubungan dengan triloka atau tribawana yaitu dunia tengah tempat manusia hidup dengan badan wadhag atau jasmaninya; dunia atas tempat Tuhan Yang Esa; serta dunia bawah tempat mahluk atau manusia yang jalan hidupnya tidak benar (dur angkara). Dengan kata lain dari komposisi rakit tigatiga dapat diketahui ajaran hidup manusia Jawa yang menganggap bahwa dunia dengan semua mahluk hidup yang ada di dalamnya, harus dipersatukan secara harmonis, selaras, dan seimbang, untuk mencapai kehidupan yang aman sentosa. 


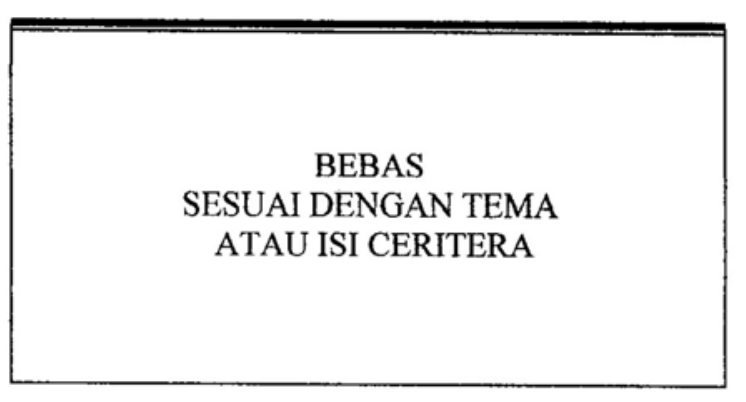

Gambar 5. Komposisi Rakit Gelar

Untuk mencapai kesempurnaan hidup, secara Islami manusia harus melewati empat tahapan yaitu sembah raga (sarengat) atau membersihkan diri secara lahir (bersifat jasmani), yang menghasilkan tatanan atau aturan-aturan. Kedua: sembah cipta (tariqat) syari'at) yang harus dicapai dengan cara membersikan hati guna menghasilkan tindakan. Ketiga: sembah jiwa (hakekat) merupakan laku batin untuk memelihara kehidupan rohani dalam mencapai kesempurnaan. Keempat adalah sembah rasa (makrifat) yaitu laku untuk mencapai rasa sejati, sehingga menyadari bahwa semua yang terjadi di dunia ini merupakan sebuah kasunyatan/ kenyataan yang tidak terelakkan. Empat ajaran itu pada komposisi tari bedhaya terefleksi dalam bingkai empat figur penari apit ngajeng, apit wingking, endhel wedalan ngajeng serta endhel wedalan wingking (Brongtodiningrat, 1981:18). Pemahaman terhadap kasunyatan itu menimbulkan rasa pasrah/sumarah pada kekuasaan Tuhan Yang Maha Esa karena perjuangannya telah sampai ke titik akhir, ke inti ceriteranya. Tahap ini terwakili dalam komposisi 'rakit gelar' di mana manusia tinggal memetik buah dari perilaku hidupnya untuk mencapai pemahaman mengenai jumbuhing kawulaGusti atau curiga manjing warongko.

Dengan demikian dapat dikatakan bahwa filosofi tari bedhaya terangkum dalam ajaran ngelmu sangkan paran yang meliputi tiga hal, pertama berkenaan dengan kesadaran bahwa manusia berasal dari Tuhan (urip iki saka sapa); kedua, berkaitan dengan tugas dan kewajiban manusia di dunia (urip iki arep apa); dan ketiga, berhubungan dengan kepulangan manusia kembali kepada Tuhannya (urip iki pungkasane piye). Dari berbagai keterangan tersebut jelas bahwa nilai-nilai tari bedhaya berhubungan dengan masalah moral dan etika yang berguna sebagai pembentuk watak seseorang yang keberhasilanya banyak dipengaruhi oleh kadewasaning jiwa atau kematangan jiwanya. Oleh karena itu, manusia Jawa dituntut untuk menjaga nilai etika moral dengan bersikap ririh (hati-hati, mawas diri), rereh (sabar, mampu mengekang diri), ruruh (tenang), sumarah (pasrah), lila legawa (tulus iklas), dan menep (mampu mengendalikan diri, tenang). Nilai-nilai seperti itu, sesungguhnya memiliki kontribusi sebagai pembentuk karakter bangsa, yang saat ini mengalami kemerosotan.

\section{Nilai Estetis}

Berdasarkan pandangan Max Scheler tentang keindahan, ada perbedaan antara keindahan sebagai nilai, dengan ide keindahan sebagai suatu konsep. Nilai keindahan (estetika) dapat ditangkap langsung terutama melalui emosi atau perasaan, tetapi ide keindahan hanya dapat diketahui secara intelektual. Oleh karena itu, orang dimungkinkan dapat menangkap dan merasakan nilai keindahan, meskipun secara konseptual orang tersebut belum tentu dapat menjelaskan tentang ide keindahan tersebut (Wahana, 2004:44). Estetika tari Jawa selain terletak pada persoalan rasa, secara indrawi dapat dilihat dari estetika gerak, tata rias, dan tata busananya.

\section{Estetika Gerak}

Estetika gerak tari kraton tidak terlepas dari gerakan-gerakan baku yang telah ada. Gerakan baku terdiri dari kemapanan gerak leher, badan, paha, kaki, tangan merupakan kristalisasi penyempurnaan gerak yang dilakukan para ahli tari selama berpuluh tahun. Ketentuan estetis dari masing-masing gerak tentu berbeda antara gerak putri, putra alus, dengan putra gagah.

Estetika gerak tari putri berpedoman pada batas-batas etika perempuan timur, khususnya pada etika putri kraton yang disesuaikan dengan ketentuan baku sebagai 
berikut: Pertama, Posisi kaki (mlumahing pupu) yang berfungsi untuk menjaga keseimbangan agar gerak tarinya agar tampak stabil, luwes, fleksibel. Kedua, Perut nglempet (dikempiskan) untuk menjaga ' $\mathrm{deg}^{\prime}$ atau sikap badan agar

tulang belakang terlihat tegak. Ketiga, pandangan sedikit menunduk disesuaikan dengan karakter tairnya. Keempat, Posisi lengan kurang lebih 30 derajad (tidak boleh terlalu tinggi) disesuaikan dengan tubuh penarinya, atau sebatas tangan pada posisi ngapurancang. Kelima, Perpindahan gerak leher dilakukan dengan halus sesuai karakter yang diperankan.

Untuk dapat disebut estetis, gerak tari yang dilakukan masih harus memenuhi kreteria luwes, patut, dan resik (Suryobrongto, 1981: 66). Tiga hal itu turut menentukan apakah gerak tari tersebut dapat disebut estetis karena keindahan suatu gerakan ditentukan pula oleh keluwesan dalam mengisi rasa gerak, dan kemapanan si penari dalam melakukan gerakan. Seorang penari dikatakan luwes, apabila dia tidak terlihat kaku, wajar dalam membawakan tariannya. Kepekaan terhadap irama gending dan irama gerak membuahkan kecermatan dan ketepatan gerak, sesuai dengan ketentuan teknik tari yang dikuasai seorang penari sehingga gerakannya bersih dilihat. Patut, berhubungan dengan wanda seseorang (karakter wajah seseorang). Orang yang mempunyai raut muka gagah, tidak cocok diberi peran alus, demikian sebaliknya orang yang berwajah halus tidak akan diberi peran bengis atau kasar. Ketentuan tidak baku ini penting untuk dijalankan seorang penari, supaya dapat mengungkapkan karakter tari yang dibawakan secara tepat (dalam istilah tari disebut lenggah).

\section{Tata Busana}

Seni pertunjukan baik berupa teater, pertunjukan tari, ataupun musik, tentu tidak lepas dari keberadaan seni pendukung lainnya seperti seni suara, seni gerak, atau seni rupa (dapat berwujud permainan warna, busana, atau make-up). Mengutip pendapat
Emannuel Kant dalam Dharsono berjudul Estetika, disebutkan bahwa ada dua macam nilai estetika dalam seni sebagai berikut: Pertama, Nilai estetis murni yang terdapat pada garis, bentuk, warna, gerak, tempo, dan irama dalam seni tari, suara, metrum, irama dalam seni musik, atau berupa dialog, ruang, dan gerak dalam seni drama karena nilainya murni, maka unsur keindahannya dikatakan keindahan murni.

Kedua Nilai ekstra estetis atau nilai tambahan. Terdapat pada diri manusia seperti gerak lambaian, sembahan, suara tangis, keindahan alam, binatang, dan lainlain. Keindahan yang terdapat pada unsurunsur tersebut disebut keindahan luar estetis atau nilai tambahan (Dharsono, 2007: 13).

Pada sebuah karya tari estetika busana atau keindahan busana turut mempengaruhi keberhasilan suatu pertunjukan. Kadang-kadang secara keseluruhan baik koreografinya, musik, tata panggung, tata lampu, dan para pendukung pertunjukan unggul dalam beberapa kriteria, tetapi tata busananya kurang mendukung, maka bobot karya tari itu menjadi berkurang. Contohnya, sebuah pertunjukan dengan objek ceritera dari Bali, tetapi memakai kostum Jawa dengan warna-warna kain sogan, tentu akan membuat penonton mengerutkan dahi. Apalagi jika hal semacam itu terjadi pada sebuah lomba tari, pastilah akan mempengaruhi hasil penilaian. Oleh sebab itu, busana juga harus menjadi pusat perhatian, terlebih jika menyangkut tentang tema sejarah, yang artinya ceritera itu memang benar-benar pernah terjadi. Pada titik ini dituntut kejelian seorang penata busana untuk mencermati busana yang akan ditampilkan sesuai dengan lakon, tempat kejadian, dan situasi yang ingin ditampilkan. Tata busana tidak sekedar memenuhi kebutuhan estetis, tetapi juga berkaitan dengan gaya atau aliran, perkembangan seni, dan sebagainya.

Estetika busana bedhaya (Sunaryadi, 2012:171-177) sangat kaya akan makna. pada perkembangannya tari bedhaya, ada tiga macam busana yang digunakan yaitu busana yang mengacu pada masa pemerintahan Sultan 
Hamengku Buwana VII (dibedakan antara masa awal sampai pertengahan pemerintahannya, dengan masa akhir pemerintahan H.B. VII), serta busana pada masa Hamengku Buwana VIII. Tata busana bedhaya sampai pada pertengahan pemerintahan Sultan Hamengku Buwana VII (1877-1921) menggunakan busana basahan atau dodotan.

Kain kampuh/ dodot berukuran dua kali panjang dan dua kali lebar kain biasa, dengan motif semen atau dapat juga memakai motif kain parang rusak barong, serta menggunakan rias muka yang disebut paes ageng. Lukisan tanaman pada batik semen diibaratkan pohon kehidupan atau sering juga diartikan sebagai pohon hayat pilar penyangga cakrawala. Hal itu juga dianggap sebagai lingga yang menyebarkan benih-benih kehidupan. Kata semen sendiri mempunyai konotasi semi atau tumbuh sebagai lambang kesuburan, keabadian, pelestarian, kemakmuran, dan simbol alam semesta. Pada motif semen terdapat lukisan lain berupa gunung atau meru, burung, garuda, sayap, pavilliun atau candi, dan gambar naga. Ornamen gunung atau meru menjadi simbol bumi, tanah tempat hidup semua mahluk Tuhan. Meru atau gunung merupakan tempat bersemayamnya arwah nenek moyang atau tempat tinggal para dewa dan pertapa.

Lukisan meru sering disebut pavilliun, digambar dalam bentuk rumah beratap segi tiga, kadang-kadang disertai tangga menyerupai bentuk candi tempat pemujaan yang diangap sakral. Pavilliun dapat pula diartikan sebagai tempat meditasi untuk mencapai kesucian dan kesempurnaan hidup. Bentuk meru digambar secara bersambung, tersusun ke bawah di letakkan di tempat tersembunyi di antara dua lukisan sayap, atau di sekeliling sulur-sulur, dan dipuncak lukisan gunung. Ornamen sulur dapat berbentuk gelombang atau melingkar, sebagai lambang kesuburan dan pertumbuhan. Kata sulur berkaitan dengan falsafah Jawa sempulur atau nunggak semi, yaitu menciptakan sesuatu yang baru dari yang telah ada sebelumnya. Hal ini ada konotasi regenerasi atau pembaharuan.

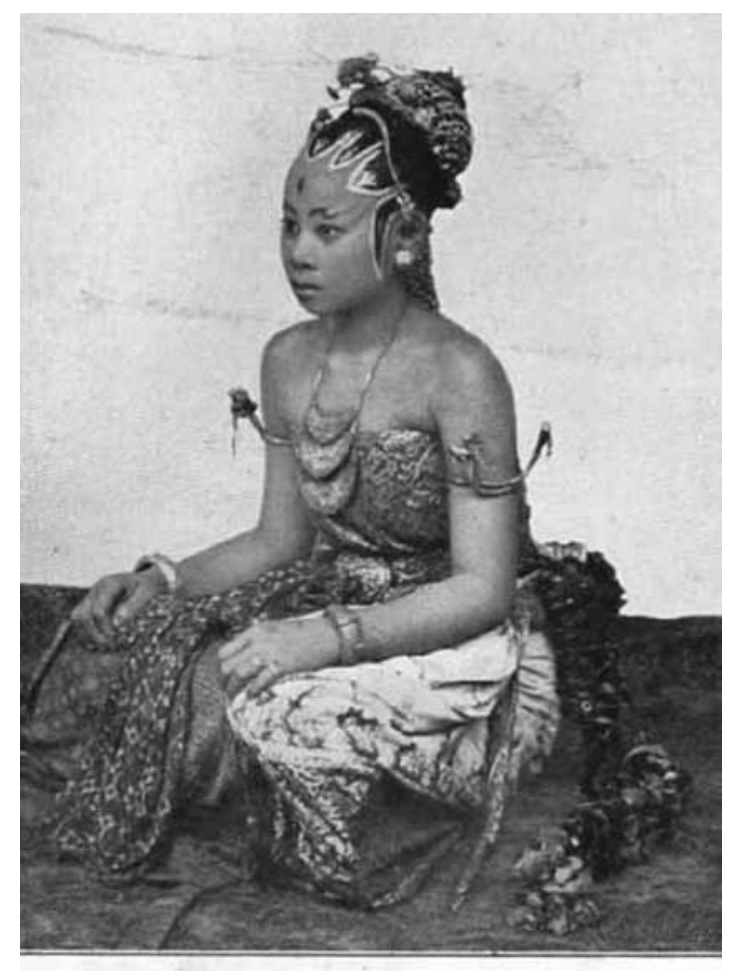

Een Jogja'sche bruid.

Gambar 6. Penari Bedhaya

(Foto: Chepas, KITLV, Leiden, reproduksi oleh Dimas 2009).

Di antara sulur-sulur sering ditemukan lukisan burung yang melambangkan kehidupan dunia atas dan dewa-dewa, atau lukisan binatang mitologi terutama naga yang merupakan simbol kekuatan dan kesaktian (Jasper, 1916: 213). Tari bedhaya biasanya memakai motif semen ageng yang ornamen pokok maupun isen-isennya paling lengkap terdiri dari ornamen meru, gurdha, sawat, lar, dan pohon-pohon (pohon hayat). Motif meru dan pohon hayat pada batik tradsional Jawa melambangkan proses kehidupan dengan empat anasir yang menyertai. Di Kraton Yogyakarta motif semen dikenakan oleh para bangsawan yang menyandang gelar bupati nayaka, bupati anom, riya bupati, penghulu, istri para pangeran, cucu dan cicit sultan. Satu perkecualian bahwa motif semen tanpa lukisan gunung atau meru, sawat, dan bentuk lar, boleh dipakai siapa saja tanpa harus memperhitungkan garis keturunannya (Condronegoro, 2010: 54). 
Pada akhir pemerintahan Sultan Hamengku Buwana VII busana yang dikenakan para penari bedhaya sedikit berubah. Busanabedhaya terdiri dari kain batik biasa (bukan dodot) dengan motif parang rusak barong yang dipakai dengan model seredan, sedangkan tata riasnya tetap menggunakan rias paes ageng gaya Yogyakarta.

Sultan Hamengku Buwana VIII (19211939) yang bertahta kemudian, banyak melakukan pembaharuan dan perubahan dalam seni pertunjukan termasuk busana tarinya. Pada masa pemerintahannya busana bedhaya menggunakan baju rompi lengan pendek model Eropa dengan hiasan ornamen (bludiran) dan rumbai-rumbai. Untuk hiasan kepala dipakai jamang dari kulit dengan hiasan bulu-bulu burung Kasuwari. Komposisi busana dengan rompi dan hiasan bulu-bulu unggas seperti itu sebelumnya hanya dipakai oleh para penari bedhaya kakung (penari putra yang menarikan tari putri). Konon dipakainya bulu-bulu ini karena H.B. VIII mengagumi tarian cancan dari Perancis. Tarian dengan bulu-bulu burung merupakan ciri tata busana tari yang berkembang di Asia Tenggara saat itu (Hughes, 2009: 66).

Selain motif batik semen, yang sering dipergunakan sebagai kelengkapan kostum bedhaya adalah motif batik parang rusak barong. Ada beberapa penafsiran dalam mengartikan motif parang. Rouffaer dan Joynboll mengatakan bahwa motif kain berpola pedang ini dikenakan oleh para kasatria atau penguasa yang sering pergi berperang. Versi lain menyebutkan bahwa parang rusak diciptakan oleh Sultan Agung ketika sedang mengamati gerak ombak Laut Selatan yang menerpa karang-karang di tepi pantai, sehingga garis-garis lengkung pada pola parang sering diartikan sebagai ombak lautan yang menjadi pusat tenaga alam (dalam hal ini yang dimaksudkan adalah raja). Komposisi miring pada parang menjadi lambang kekuasaan, kebesaran, kewibawaan, dan gerak cepat, maka para pemakai parang diharapkan dapat bergerak cepat dan gesit.

Di dalam "Ryksblad van Djokjakarta" tahun 1927, tentang Pranatan Dalem Bab
Jenenge Panganggo Keprabon Ing Kraton Nagari Ngayogyakarta, menyebutkan beberapa perbedaan antara ketentuan pemakaian nyamping/bebet, dengan kampuh atau dodot. Kampuh atau dodot motif parang rusak barong ini hanya boleh dipakai oleh sultan, permaisuri, istri utama sultan, putra mahkota, putra dan putri sulung sultan, Kanjeng Panembahan, dan Kanjeng Gusti Pangeran Adipati (K.G.P.A.), serta putra sulung sultan. Tata aturan itu membuktikan betapa tingginya kedudukan bedhaya dalam hirarki kraton. Bedhaya menjadi lambang kekuasaan sejajar dengan kedudukan sultan dan para bangsawan utama di dalam kraton.

\section{Tata Rias}

Tata rias bedhaya (Sunaryadi, 2012:177180) menggunakan riasan paes ageng gaya Yogyakarta. Pilihan mengunakan paes ageng ini berdasarkan beberapa pertimbangan di antaranya bahwa selain paes ageng lazim dipergunakan di dalam sebuah pertunjukan bedhaya. Rias paes ageng ini juga mencerminkan keagungan, kedewasaan, dan ketenangan, yang dalam bahasa Jawa dikenal dengan istilah wanda-luruh. Tentunya ini selaras dengan kriteria tari putri gaya Yogyakarta yang harus tenang-anggun (luruh-jetmika), dan tidak rongeh (banyak tingkah). Keseluruhan tata rias wajah yang disebut 'paes' terdiri dari penunggul, pengapit, dan penitis yang berbentuk runcing seperti gunung merupakan simbol keberadaan Trimurti (Brahma, Wisnu, dan Syiwa) tiga dewa pemberi kebahagiaan umat manusia, lambang kemakmuran, dan sumber kehidupan. Di tengahnya diisi hiasan berbentuk capung atau kinjengan, seekor binatang yang selalu bergerak tanpa lelah, yang bermakna pengharapan agar di dalam menjalani kehidupan, orang selalu ulet, tekun, pantang menyerah seperti gerak kinjeng.

Di bawah penunggul di antara kedua mata agak ke atas diberi cithak atau widheng dibuat dari daun sirih berbentuk belah ketupat sebagai lambang mata Syiwa atau pusat panca indra, sebagai pusat dari keseluruhan daya cipta manusia. Alis berbentuk menjangan ranggah. Menjangan atau rusa adalah binatang 
yang cekatan. Ini mengingatkan bahwa dalam menghadapi permasalahan hidup, orang diharapkan dapat bertindak cekatan. Daerah sekeliling mata dibiarkan tak terjamah oleh boreh dan diberi gambaran yang disebut jahitan. Jahitan dibentuk sedemikian rupa sehingga bentuk mata terlihat lebih tajam, dan sangat jelas terlihat jika melirik ke kanan atau ke kiri, dengan riasan seperti itu memaksa orang untuk bersikap tenang, berpandangan lurus ke depan.



Gambar 7. Kain kampuh dengan motif parang rusak barong,dikenakan oleh G.K.R. Pembayun putri sulung H.B. $X$ dalam pentas tari Bedhaya

Sang Amurwabumi karya Sultan H.B. X, di Bangsal Kencana Kraton Yogyakarta tahun 2001.

(Foto: Santoso Alimin tahun 2001).

Gelung (sanggul) dibuat seperti bentuk bokor mengkurep melambangkan keberadaan bumi, dan diisi dengan daun pandan yang ditutup untaian melati. Perpaduan antara daun pandan dan bunga melati memancarkan keharuman yang berkesan religius merupakan simbol pengharapan agar si pemakai dapat membawa nama harum dan berguna bagi masyarakat.

Prinsip hidup yang ingin disampaikan lewat kelengkapan busana, terlihat pula dari makna raja keputren yang dikenakan. Sebagian raja keputren atau asesori mempunyai arti tersendiri, seperti sengkang ronyok berdasar warna hitam diartikan sebagai harapan terciptanya keabadian.

Sangsangan sungsun atau kalung bersusun tiga, perlambang tiga tingkatan kehidupan manusia dari lahir, kawin, dan mati yang dihubungkan dengan konsepsi Jawa tentang alam baka, alam antara, dan alam fana, atau antara jagad cilik, jagad gedhe, dan jagad gumelar (Herusatoto, 1988: 99).

Gelang kana berbentuk melingkar tanpa batas ujung pangkalnya mempunyai makna keabadian dan kesetiaan. Kata 'kana' berarti simpai atau 'suh', maka pemakai gelang kana harus sadar akan fungsinya sebagai suh atau sebagai yang bertanggungjawab (Kawindrasusanta, 1981:164-176). Cundhuk mentul sebagai hiasan kepala merupakan gambaran sinar matahari yang berpijar memberi kehidupan. Kelat bahu atau hiasan lengan berbentuknaga melingkar disebut naga mangsa, menjadi lambang bersatunya pola rasa dengan pola pikir yang mendatangkan kekuatan. Kelat bahu dipakai menghadap ke belakang, sebagai simbol penolak bahaya yang datang dari arah belakang. Di dalam kepercayaan Jawa, banyak binatang mitologi yang diyakini dapat membawa keberuntungan dan keselamatan terutama binatang dari dunia atas seperti garuda (banyak terdapat pada lukisan kain bermotif semen ataupun parang), serta binatang mitologi dunia bawah khususnya naga yang diyakini akan membawa kemakmuran, dan perlindungan dari bahaya yang bersifat gaib. Binatang naga tidak saja dilukiskan pada motif kain, tetapi juga pada bentuk kelengkapan busana lainnya seperi pada kelat bahu, kalung, gelang, bahkan untuk ukiran kepala kapal, dan ukiran pedaringan (tempat tidur tradisional Jawa). Naga juga merupakan simbol berdirinya Kraton Yogyakarta pada tahun 1755 (Jawa: 1682) yang dilukiskan dalam sengkalan memet berbentuk dua ekor ular naga berwarna hijau (sebagai simbol ketenangan dan ketentraman) yang saling berlilitan ekornya (dwi naga rasa tunggal). Sebuah relief yang terdapat pada renteng batu rana (tembok panjang) bagian dalam 
regol Kemagangan. Ukiran naga yang dipilih merupakan stilisasi dari naga bumi atau naga pretala, untuk mengingatkan kepada para penguasa bahwa tegaknya sebuah negara karena adanya dukungan golongan bawah atau rakyat. Dengan demikian rias dan busana tari bedhaya mengandung pesan-pesan moral dan spiritual yang pada hakikatnya berfungsi sebagai mekanisme kontrol terhadap pribadi dan lingkungan.

\section{SIMPULAN}

Berdasarkan ulasan di atas jelas, bahwa tari bedhaya secara aksiologis memuat nilai etis dan estetis. Dilihat dari dimensi etisnya tari bedhaya merupakan wujud imanensi antara Tuhan dan manusia yang tercitrakan dari kawruh manunggaling kawula-Gusti. Kawruh atau pengetahuan yang didasarkan pada ajaran sangkan paraning dumadi, mengenai keterkaitan manusia dengan hakikat asal muasal dan tujuan sejatinya sebagai makluk ciptaan Tuhan. Muatan nilai etis bedhaya itu secara detail tergambar pada komposisi dan formasi tarinya yang meliputi rakit lajur, rakit ajeng-ajengan, rakit iring-iringan, rakit tiga-tiga, dan rakit gelar, sedangkan muatan estetis tari bedhaya tergambar pada gerak tari, tata busana, dan tata rias. Keindahan gerak tari bedhaya terjabarkan dalam tiga kata, yaitu luwes, patut, dan resik. Adapun nilai keindahan tata busananya bisa dilihat dari filosofi busana dodotan, serta tata riasnya yang terangkum dalam rias paes ageng gaya Yogyakarta.

Filsafat tari bedhaya mancakup berbagai nilai moralitas, spiritualitas, sosial, maupun keagamaan. Dari segi etika-moralitas (moral values) lampah bedhaya mengajarkan manusia bagaimana harus bersikap dan berperilaku serta mengarahkan manusia untuk berolah rasa, berolah kalbu, dan guna mempertajam sensibilitas atau daya tanggap hingga pandai mengendalikan diri dan mampu berkelakuan baik, guna menuju manunggaling kawula-Gusti sebagai tujuan akhir hidup manusia. Dengan demikian, tari di dalam kraton mengandung ajaran yang menempatkan "rasa sebagai ruh" dan "pengendalian diri sebagai inti". Pengendalian emosi adalah aspek pokok yang diajarkan di dalam tari. Oleh karena itu, tari di dalam Kraton Yogyakarta bukan sekedar tontonan juga merupakan sebuah media yang mengandung tuntunan untuk bersikap baik dan benar. Nilai-nilai tari kraton berisi tentang kehidupan yang dibingkai dengan kearifan serta petuah-petuah, dan dikemas dalam bahasa simbol berupa gerak tari, pola lantai, iringan, dialog, maupun dalam tata rias dan busananya. Belajar menari sama dengan belajar etika moral, yang menuntut kedisiplinan, ketekunan, kesabaran, keuletan, dan semangat pantang menyerah. Aturan baku di dalam tari yang tidak boleh dilanggar, serta alur ceritera yang memuat nilai kebenaran, kebaikan, dijadikan pedoman hidup dalam bersikap dan berperilaku bagi masyarakat kraton, sebagai pribadi maupun sebagai mahluk sosial. Dengan demikian, sesungguhnya tari kraton merupakan suatu 'dedication of life' (pandangan hidup), mengenai sikap mawas diri (introspeksi), tepa slira (toleransi), narima (menerima apa pemberian Tuhan), tatag (tabah), tangguh (tidak tergoyahkan), tanggap (cepat mengerti) manembah (menyembah) kepada Allah, waspada (waspada), ngatiati (hati-hati). Berbagai nilai-nilai lama itu banyak yang berlaku universal, artinya hampir semua suku (etnis) memiliki keyakinan serupa, seperti mengakui keberadaan Tuhan Yang Maha Esa, memiliki rasa kemanusiaan, toleransi, persatuan, keadilan, gotong royong, musyawarah, yang sebenarnya dengan kesepakatan bersama semuanya telah terangkum dalam sila-sila Pancasila sebagai dasar negara Indonesia.

\section{DAFTAR PUSTAKA}

Bagus, Lorens. 1996. Kamus Filsafat. PT. Gramedia Pustaka Utama. Jakarta.

Blackburn, Simon.1994. The Oxford Dictionary of Philosophy. Oxford University Press. Oxford-New York.

Brongtodiningrat, KRT.1979. Lelangen Dalem Bedhoyo Sarta Srimpi Hing Ngayogyakarta Hadiningrat. Proyek NKK ASTI Yogyakarta. Yogyakarta. 
Condronegoro, Mari,S. 2010. Memahami Busana Kraton Yogyakarta: Warisan Penuh Makna. Yayasan Pustaka Nusatama. Yogyakarta.

Dharsono (Sony Kartika). 2007. Budaya Nusantara: Kajian Konsep Tri-loka terhadap Pohon Hayat pada Batik Klasik. Rekayasa Sains. Bandung.

Frondizi, Resieri. 1963. What is Value. Translated by Solomon Lipp. Oprn court Publishing Company. Illinois.

Herusatoto, Budiono. 1988. Simbolisme Dalam Budaya Jawa. Hanindita. Yogyakarta.

Hughes, Felicia-Freeland. 2009. Komunitas yang Mewujud: Tradisi Tari dan Perubahan di Jawa. Terj. Nin Bakdi Soemanto. Gadjah Mada University Press. Yogyakarta.

Jasper, J.E.dan Pierngadi. 1916. De Inlandsche Kunstnijverheid in NederlandIndie. Mounton \& Co, De Hague. Rotterdam.

Kaelan, M.S. 2005. Metode Penelitian kualitatif Bidang Filsafat. Pardigma. Yogyakarta

Kattsoff, Louis O.1987. Pengantar Filsafat. alih bahasa Soejono Soemargono. Tiara Wacana. Yogyakarta .

Kawindrasusanta, Kuswadji. 1981. “Tata Rias Busana Tari Gaya Yogyakarta" dalam Mengenal Tari Klasik Gaya Yogyakarta. Dewan Kesenian Propinsi DIY dan Proyek Pengembangan Kesenian DIY, Departemen P\&K. Yogyakarta:

Koentjaraningrat. 1987. Kebudayaan mentalitas dan Pembangunan. Gramedia. Jakarta.

Koentjoroningrat.1976. Kebudayaan Jawa. Gramedia. Jakarta.

Maharsiwara, Sunaryadi. 2007. Dwi Naga Rasa Tunggal: dari Sengkalan Memet ke Seni Pertunjukan. Pondok Edukasi. Yogjakarta.
Mangkunegoro IV.1975. Wedhatama. Yayasan Mengadeg. Surakarta.

Perry, Ralp Barton.1954. Realms of Value, A Critic of Human Civilization. Harvard University Press. Cambridge. Mass.

Scheler, Max. 1973. Formalism in Ethics and Non-Formal Ethics of Values: A New attempt toward the foundation of an ethical personalism. translated by Manfred S. Frings and Roger L. Funk. Northwestern University Press. Evanston, Illinois.

Soedarso SP. 2000. Sejarah Perkembangan Seni Rupa Modern. Studio Delapan Puluh Enterprise. Yogyakarta.

Soedarsono, RM. 1997. Wayang Wong Drama Tari Ritual Kenegaraan di KratonYogyakarta. Gadjah Mada University Press. Yogyakarta.

Sunaryadi. 2012. "Nilai-Nilai Tari Kraton Yogyakarta: Relevansinya bagi Penanaman Karakter Bangsa". Disertasi Program Doktor Ilmu Filsafat Fakultas Filsafat UGM. Yogyakarta. .2012. Filsafat Joged Mataram: Media Penanaman Karakter. Sekolah Pasca Sarjana UGM. Yogyakarta.

Suryobrongto, GBPH. 1981. Mengenal Tari Klasik Gaya Yogyakarta, dalam Fred Wibowo, (editor). Dewan Kesenian Propinsi DIY Dan Proyek Pengembangan Kesenian DIY, Departemen P dan K. Yogyakarta.

Suseno, Frans-Magnis. 2001. Etika Jawa: Sebuah Analisa Falsafi tentang Kebijaksanaan Hidup Jawa. Gramedia. Jakarta.

Titus, Harold H. dkk. 1984. Persolan-persolan Filsafat. Terj. H. M. Rasjidi. Bulan Bintang. Jakarta.

Wahana, Paulus. 2004. Nilai Etika Aksiologis Max Scheler. Kanisius. Yogyakarta. 